\title{
US-Anti-Dumping Measures on Certain Shrimp from Viet Nam: A Stir-Fry of Seafood, Statistics, and Lacunae
}

\author{
TOMER BROUDE* \\ Hebrew University of Jerusalem \\ MICHAEL MOORE** \\ George Washington University
}

\begin{abstract}
This unappealed Panel Report deals with now standard controversies involving US zeroing practices, but also involves a number of novel problems in administrative reviews of US anti-dumping orders that transcend zeroing issues. Most importantly, this dispute highlights the economic, legal, and statistical importance of sample-selection bias when calculating 'all others' rates for exporters that were not queried during dumping investigations. Sampling is particularly problematic in this dispute since US investigators found only zero and de minimis margins in the administrative reviews, a situation in which the relevant provision of the Anti-Dumping Agreement appears to provide no guidance (an apparent 'lacuna'). The Panel did not directly deal with the key sample-selection issues in the case, and so we provide an alternative legal and statistical analysis. These issues are likely to become more important as the practice of zeroing is phased out in the United States. Indeed, sampling may well be the new zeroing.
\end{abstract}

\section{Introduction: much more than zero(ing)}

At first glance United States-Anti-Dumping Measures on Certain Shrimp from Viet Nam (US-AD Shrimp $)^{1}$ could easily be mistaken for simply yet another in the long series of 'zeroing' disputes adjudicated by the WTO dispute-settlement system. Ever since India filed a case in EC-Bed Linen (2001), ${ }^{2}$ at least 16 distinct

\footnotetext{
* Sylvan M. Cohen Chair in Law, Faculty of Law and Department of International Relations; Academic Director, The Minerva Center for Human Rights, Hebrew University of Jerusalem; Email: tomerbroude@ gmail.com.

* Professor of Economics and International Affairs, Institute for International Economic Policy, Elliott School, George Washington University; Email: mom@gwu.edu.

We would like to thank participants Chad Bown, Niall Meagher, Tom Prusa, and Edwin Vermulst for helpful discussion about an earlier draft. All errors are of course our own.

1 Panel Report, United States-Anti-Dumping Measures on Certain Shrimp from Viet Nam, WT/DS404/R, adopted 2 September 2011.

2 Appellate Body Report, European Communities - Anti-Dumping Duties on Imports of Cotton-Type Bed Linen from India, WT/DS141/AB/R, adopted 12 March 2001, DSR 2001:V, 2049.
} 
complaints have been filed at the WTO relating to variants of the zeroing methodology used in dumping calculations. ${ }^{3}$ In such investigations, authorities ascribe a 'zero' margin to any transaction where the export price exceeds the 'normal' price (i.e., in which the dumping margin is negative), thereby inflating the resulting calculated dumping margin (Voon, 2011). The vast majority of these complaints have been brought against the US, which has proven reluctant to amend its methodologies and only recently announced significant changes in policy and legislation (Cho, 2012).

$U S-A D$ Shrimp can indeed be read as a late chapter in the zeroing saga. Viet Nam complained against the use of zeroing in the calculation of dumping margins, both 'as applied' and 'as such', referring both to the implications of zeroing used during the original investigation, and to the WTO consistency of zeroing employed in subsequent periodic administrative reviews. On these issues, the Panel, whose Report was not appealed by either the US or Viet Nam, generally followed the lines of analysis set out by the Appellate Body in prior jurisprudence, finding US zeroing practice to be WTO-inconsistent. ${ }^{4}$ Besides one or two relatively minor points, the Panel in US-AD Shrimp was not asked to rule on any particularly novel issues relating to zeroing in dumping calculations. ${ }^{5}$

However, US-AD Shrimp has several dimensions of interest that transcend the question of zeroing. In particular, as we shall set out in more detail below, the dispute provides us with an opportunity to analyze the statistical, economic, and legal implications of sample-selection practices employed by investigating authorities in anti-dumping proceedings.

Under the terms of the second sentence of Article 6.10 of the Anti-Dumping Agreement (ADA), ${ }^{6}$ Members may limit their investigation to a sample of relevant firms when faced with a large number of enterprises involved in the product market under investigation (sometimes known as 'limited examination'). In structural-legal terms, this possibility is an exception to the general rule whereby the investigating authorities should determine 'an individual margin of dumping for each known exporter or producer concerned of the product under investigation', 7 but sampling

3 For legal and economic analyses of zeroing in anti-dumping cases, see Bown and Sykes (2008), Prusa and Vermulst (2009), Prusa and Vermulst (2011), and Bown and Prusa (2011).

4 See US-AD Shrimp, paras. 8.1(b) and (c).

5 As the Panel noted understatedly, US-AD Shrimp was 'not the first time US practices in relation to zeroing have come before a WTO panel'. However, the facts of the case were 'unusual' in that all of the individually calculated dumping margins in the relevant administrative reviews were either zero or de minimis, thus raising the question of whether zeroing is WTO-inconsistent even when it does not lead to the imposition of duties on firms with an individually calculated dumping margin (see US-AD Shrimp, para. 7.82). We address this issue in Section 2.2.2.

6 Agreement on Implementation of Article VI of the General Agreement on Tariffs and Trade 1994, Annex 1 A, Marrakech Agreement establishing the World Trade Organization, 15 April 1994, Final Act Embodying the Results of the Uruguay Round of Multilateral Trade Negotiations, Legal Instruments: Results of the Uruguay Round, 6, 6-18; 33 I.L.M. 1140, 1144-1153 (1994).

7 Article 6.10 ADA, first sentence. 
is hardly an uncommon practice among investigating authorities. Indeed, it is so common that Viet Nam argued against US Department of Commerce's repeated use of limited examinations in anti-dumping investigations as having 'effectively turned the general rule in the first sentence of Article 6.10 ADA (i.e., that an individual margin should be determined for each exporter/producer) into an exception, and the exception under the same provision into a general rule' ${ }^{8}$

The way domestic administrators select the sample of individually assessed firms may have crucial repercussions on firms left outside of the sample because, in accordance with Article 9.4 ADA, the anti-dumping duty rate imposed upon the imports of the latter (the 'all others' rate) is linked to the dumping margins calculated with respect to the former. Moreover, exporters may still face the 'all others' rate even if they are willing to offer their own data for use by domestic authorities to calculate firm-specific rates, if investigators find that to conduct such an individual calculation would be 'impracticable', as determined by the investigators themselves. The practical consequences of this selection process could be dramatic: in the second and third administrative reviews of US-AD Shrimp, only two and three Vietnamese firms, respectively, were investigated in detail. The weighted average of this exceedingly small sample was then applied to dozens of other Vietnamese firms that were not queried about their particular economic conditions. Sample selection therefore raises interrelated questions involving both statistical analysis, on the one hand, and fairness and due process, on the other.

Surprisingly, the Article 6.10 ADA parameters for sample selection and limited examination have not merited significant interpretation in either WTO jurisprudence or academic analysis, ${ }^{9}$ and have only received peripheral attention from WTO Members concerned with reforming the ADA. ${ }^{10}$ Furthermore, the terms established by Article 9.4 ADA for the calculation of the 'all others' rate are, in certain circumstances, very vague, to the point that the Appellate Body has identified a 'lacuna' in the clause. ${ }^{11}$

These special circumstances - viz, when all the dumping margins calculated for the selected firms are either zero or de minimis - are strongly linked to the question

8 See US-AD Shrimp at para. 7.154. We address this issue in some more detail in Section 2.2.3 On ruleexception normative relationships in WTO law generally, see Broude (2007).

9 But see Panel Report, Argentina-Definitive Anti-Dumping Measures on Imports of Ceramic Floor Tiles from Italy, WT/DS189/R, adopted 5 November 2001, DSR 2001:XII, 6241, paras. 6.86-6.105, discussing the duty established by Article 6.10 ADA to establish an individual dumping margin for firms included in the sample.

10 See in particular WTO, Negotiating Group on Rules, TN/RL/GEN/46, Issues Related to Article 6.10, Including 'Limited Examination', and Article 9.4 'All Other's Rate', Paper from Brazil; Chile; Hong Kong, China; Israel; Japan; Republic of Korea; Norway; Switzerland; Separate Customs Territory of Taiwan, Penghu, Kinmen, and Matsu; and Thailand, 10 June 2005.

11 See Appellate Body Report, United States-Anti-Dumping Measures on Certain Hot-Rolled Steel Products from Japan, WT/DS184/AB/R, adopted 23 August 2001, DSR 2001:X, 4697 (hereafter US-HotRolled Steel), paras. 125-126. We address this issue in additional detail in Section 4 below. 
of sample selection. It is on the statistical and interpretative issues associated with Articles 6.10 and 9.4 ADA, and the relationship between them, that most of our analysis in this article will focus.

Before turning to a more detailed examination of US-AD Shrimp, we wish to briefly dwell on two aspects of the dispute's economic and political context.

First of all, the dispute was the first complaint filed by Viet Nam at the WTO dispute-settlement system, soon after its accession to the WTO on 11 January $2007 . .^{12}$ Indeed, the dispute relates to an original anti-dumping investigation that the US conducted prior to Viet Nam's accession. The 'Socialist Republic of Viet Nam' is a socialist/communist state lacking a tradition of participation in the international legal system but with an economic system that is undergoing a complex transition to liberalization and exposure to market forces while retaining a centralized political structure (the so-called 'socialist-oriented market economy', building on the Doi Moi economic reforms of the late 1980s and 1990s (Gantz, 2007). While monitoring the economic benefits of WTO accession (Vo Tri Thanh and Nguyen Anh Duong, 2009), Viet Nam's filing of the complaint in US-AD Shrimp represents a strong signal that it regards dispute settlement in the WTO as a legitimate and worthwhile means for enforcing its rights and promoting its interests in international trade, perhaps in emulation of the strategy of 'aggressive legalism' that has been attributed to Japan and Korea as well as post-WTO accession China (Pekkanen, 2001; Gao, 2005). Viet Nam's demeanor in US-AD Shrimp suggests that it should be regarded as a sophisticated player in the WTO, and as has been pointed out by some commentators, the case has implications for the way trade partners will treat Viet Nam as a 'non-market economy' (NME) in the WTO, ${ }^{13}$ in all sectors of importance to Viet Nam's economic development (Do Thanh Cong, 2010).

Second, again as a matter of political and economic context, the dispute discussed in this paper related to the international market for shrimp products, and as such is interconnected with a number of other WTO disputes. Since the late 1990s, demand for shrimp products has increased significantly, eagerly satisfied by exporters in various Asian countries, ultimately resulting in lower prices (Do Thanh Cong, 2010). Import controls imposed by Europe in the early 2000s, based on health concerns relating to the antibiotic treatment of farmed shrimp in countries of origin, diverted significant Asian output to North America (Debaere, 2010), with significant harm to the US shrimp industry, which led to successful petitions for

12 Consultations in the dispute were requested by Viet Nam on 1 February 2010; see US-AntiDumping Measures on Certain Shrimp from Viet Nam-Request for Consultations, WT/DS404/1, 4 February 2010.

13 A WTO Member's characterization as an NME will affect the way other Members conduct antidumping investigations with respect to imports from the NME Member. This issue was specifically addressed in Viet Nam's accession documents; see Accession of Viet Nam-Report of the Working Party on the Accession of Viet Nam, WT/ACC/VNM/48, 27 October 2006, paras. 254-255. 
anti-dumping duties imposed by the US (Keithly and Poudel, 2008). Part of the exporting countries' reaction to these duties is now on the books of WTO jurisprudence. Thus, US-AD Shrimp should be read against the backdrop of a total of seven complaints relating to US anti-dumping duties on shrimp products brought separately to the WTO by China, Ecuador, India, Thailand, and Viet Nam (including a recent follow-up complaint to US-AD Shrimp brought by Viet $\mathrm{Nam}),{ }^{14}$ some of which deal with zeroing issues. The shrimp-farming industry is an extremely important export sector for Viet Nam, and the US is a chief export market; ${ }^{15}$ Viet Nam's interests in bringing the complaint in this case are clear. However, it is worth bearing in mind that the dispute is part of a larger legal campaign by shrimp-exporting developing and emerging economies against US anti-dumping practices perceived as protectionist in a sector important for their economic development.

The article will proceed as follows. In Section 2, we will set out the relevant legal background of the dispute, including an exposition of the main practices of the US Department of Commerce (the 'USDOC') as the investigating authority; the legal basis of the complaint by Viet Nam; the US response and interventions by third parties where relevant; and the main findings of the Panel in its Report, including a critique of the Panel's hermeneutic approach to the sample-selection issues. In Section 3, we will critically analyze the issue of sample selection in limited examinations under Article 6.10 ADA, with an emphasis on insights from statistical methodologies. In Section 4, we will discuss the so-called 'lacuna' in Article 9.4 ADA with respect to the 'all others' rate of anti-dumping duties, suggesting a role for statistical analysis in the interpretation of that provision. Section 5 concludes.

\section{Legal issues in US-AD Shrimp}

\subsection{Relevant USDOC practices}

Understanding the US system of anti-dumping investigations will be critical in analyzing the US-AD Shrimp dispute. The USDOC bears the legal responsibility for investigating alleged dumping by exporters from foreign countries. ${ }^{16}$ The agency calculates dumping margins in three situations: (1) original investigations, when first determining whether anti-dumping duties should be imposed, and at which rates; (2) periodic administrative reviews, which, subject to certain terms, take place on the anniversary of the original anti-dumping order; and (3) five-year

14 See United States-Anti-Dumping Measures on Certain Shrimp from Viet Nam-Request for Consultations by Viet Nam, WT/DS429/1, 27 February 2012.

15 See the Business Times (Viet Nam) (2012).

16 See Title VII of the Tariff Act of 1930 (19 U.S.C. 1671 et seq.). 
'sunset' reviews, when the termination of the original order is at issue. ${ }^{17}$ In each type of investigation, the USDOC in principle compares the export price to the US for each foreign exporter with the 'normal' price of the good, which can be the price in the home market, a third market (if there are insufficient sales for a valid comparison in the home market), or a constructed production-cost calculation (if there are insufficient instances of the other outcomes). ${ }^{18}$ These comparisons necessarily require detailed information about foreign firms' pricing and cost data.

The USDOC conducts its investigations according to two categories of exporting states. 'Market economy' cases involve foreign firms operating in economies where prices are deemed under US law to provide accurate signals about the efficient allocation of resources. In contrast, exporters operating in 'non-market economy' (NME) cases are considered to have unreliable pricing and cost information so that USDOC investigators must use third-country surrogates to calculate the dumping margins. Viet Nam is considered an NME by US authorities and hence subject to the latter sets of procedures. ${ }^{19}$

Administrative reviews are the particular focus of US-AD Shrimp. The role of administrative reviews is especially important and derives from the 'retrospective' duty-assessment system operated by the US, whereby, upon importation, a cash deposit for anti-dumping duty liability is collected, but actual anti-dumping duties are assessed only at a later date. This assessment takes place in the periodic administrative review, which may be requested by interested parties every year, during the anniversary month of the original anti-dumping order. In an administrative review, the USDOC assesses the importer's liability for antidumping duties retrospectively on a transaction-specific basis. If no review is requested, the duty is assessed at the full rate of the cash deposits. ${ }^{20}$ We discuss the procedures for NME administrative reviews below in more detail within the specific context of the US-AD Shrimp dispute.

Specific outcomes for individual NME exporters subject to anti-dumping orders in administrative reviews depend on several factors. ${ }^{21}$ Figure 1 sets out a detailed decision tree tracing them.

17 Details of US standard procedures can be found in the Antidumping Manual (US Import Administration (2009) (the ADM)). For a description and critique of the US anti-dumping regime, see Barfield (2005).

18 See ADM, Chapter 6; and Article 2.2 ADA.

19 Section 771(18) of the Tariff Act of 1930 (supra at note 16) defines NME as 'any foreign country that the [USDOC] determines does not operate on market principles of cost or pricing structures, so that sales of merchandise in such country do not reflect the fair value of the merchandise'. The USDOC classifies states as either market economies or NMEs under its own terms (see ADM, Chapter 10). In footnote 27 in the US-AD Shrimp Panel Report, the Panel expressed 'no opinion on the WTO-consistency of the USDOC's classification of certain countries, including Viet Nam, in such a category'.

20 See US-AD Shrimp, para. 7.12.

21 These procedures are discussed in detail in Department of Commerce (DOC) (2009). 
Figure 1. US administrative review process for non-market economies

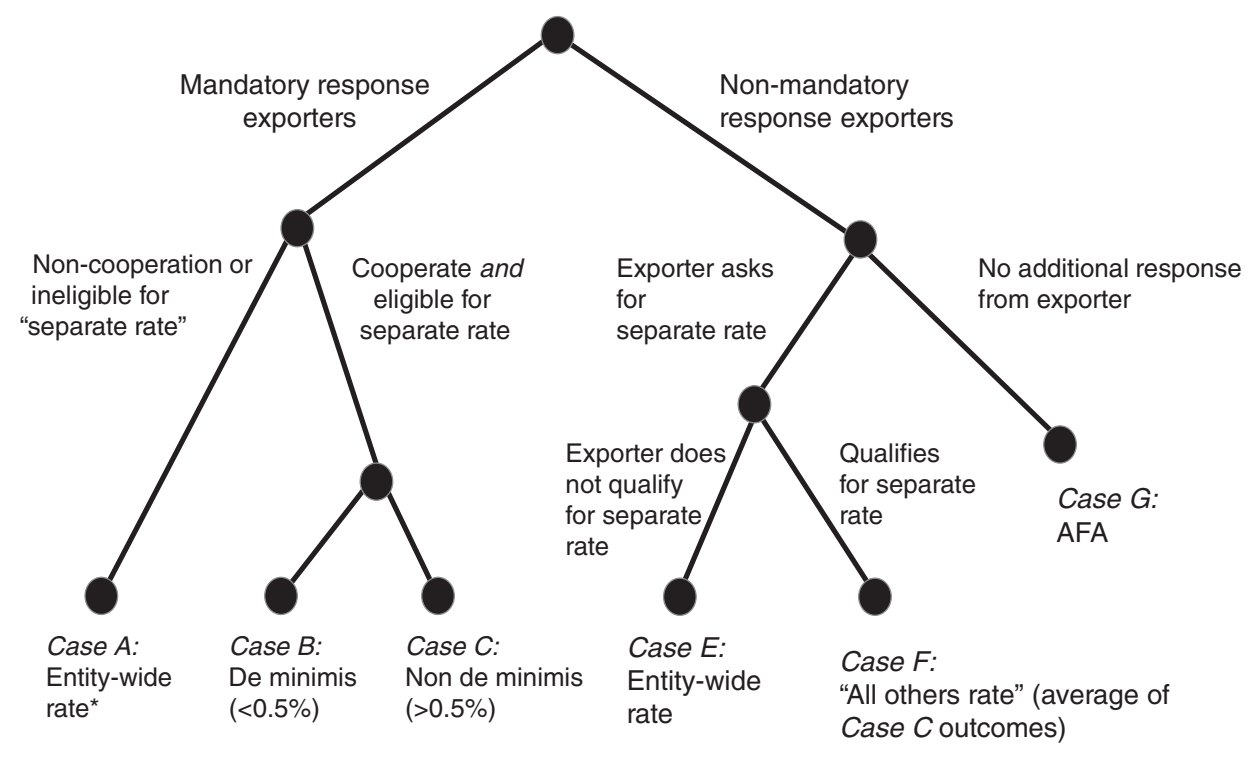

Upon the request of an interested party (in the US, or a foreign exporter) the USDOC will launch an administrative review of the original anti-dumping order. The USDOC begins from the (rebuttable) presumption that all firms in the NME will receive an 'entity-wide rate' (EWR), unless they can show to the USDOC's satisfaction that their exports are sufficiently independent of government control. Firms that meet these independence criteria may be eligible for a 'separate rate' determined independently from the entity-wide rate.

The USDOC initially sends a 'quantity and value' questionnaire to all foreign exporters that have been either: (a) identified by petitioners, or (b) those exporters who themselves have requested a review. The requested information will include the volume and value of exports to the US of the product subject to the existing anti-dumping order. ${ }^{22}$

The USDOC's investigators also determine how many foreign firms they will choose to examine in detail for the formal dumping investigation in the administrative review. In practice, the number of foreign firms investigated is limited by how many resources the USDOC chooses to devote to the case. Typically, investigators will choose a very small number of foreign exporters, who become 'mandatory respondents' for the formal review. As in the original

22 In more recent cases, the USDOC has relied on detailed data gleaned from official customs records, as in the third administrative review in US-AD Shrimp. See DOC (2009). 
investigations, only the largest exporters of the product in question to the US are considered for this category. Note that an exporter requesting an administrative review is not guaranteed to be one of the firms that the USDOC will select to receive a detailed questionnaire.

These 'mandatory respondent' firms may then choose to cooperate or not in the full-scale dumping investigation by providing detailed data (e.g., about input quantities) to the USDOC.

Mandatory respondents selected in the administrative review that do not cooperate (as determined by the USDOC investigators) will necessarily receive the EWR, which is normally the 'Adverse Facts Available' (AFA) rate determined for similarly noncooperative selected respondents in the initial investigation. The USDOC also considers that mandatory respondents that cooperate but cannot show that they are eligible for a 'separate' rate, are subject to the EWR. Both types of NME exporters are depicted as Case A in Figure 1. The margins assigned to them are deemed 'unrepresentative' and so are not included in the subsequent 'all others' rate.

Mandatory respondents that do respond adequately to the questionnaire and are deemed by the USDOC as eligible for a 'separate rate' will receive a firm-specific margin calculated in the administrative review. As in original investigations, the USDOC chooses a surrogate country it considers to be at a similar level of economic development, whose input prices are then applied to the input quantities reported by the cooperating firms, in order to calculate a dumping margin. If the specific foreign firm's calculated margin is less than a $0.5 \%$ de minimis rate (rather than the $2 \%$ de minimis rate applicable in original investigations), then that firm is not subject to an anti-dumping duty at all (Case B in Figure 1). Margins above the de minimis rate are also the basis of the anti-dumping duty going forward to at least the next administrative review for these mandatory-response exporters (Case $\mathrm{C}$ in Figure 1).

The procedures for mandatory respondents in market-economy investigations parallel the process below with the exception that there is no need to determine whether a particular exporter is eligible for a 'separate rate'. All mandatory respondents either receive an individually calculated rate or, if they do not cooperate, the AFA rate.

Let us turn now in detail to procedures used for the nonmandatory response firms in NME cases.

All firms not queried during the administrative review and that do not request separate-rate eligibility by default receive the EWR based on AFA (Case G in Figure 1). In conventional market-economy cases, all nonqueried firms normally would receive an 'all others' rate based on a weighted average of nonzero and non-de minimis margins.

A nonmandatory respondent may volunteer to provide information to the USDOC that may establish its eligibility to avoid the EWR. If the USDOC rejects this contention, then the firm receives the EWR (Case E in Figure 1). This outcome 
may also occur if the USDOC determines it is not 'practicable' to analyze more firms in the administrative review.

A nonmandatory response foreign firm that does qualify for a separate rate is designated as Case F in Figure 1. In this instance, the USDOC typically does not conduct a new investigation using that firm's individual data. Instead the USDOC will apply an 'all others' rate based on a weighted average of Case C outcomes, i.e., based on the data of other mandatory-response firms eligible for a separate rate. In a market-economy case, such a firm would receive a margin based on a separate investigation using data provided by the individual exporter. This distinction makes clear that the procedures for determining the 'all others' rate is of particular importance in an NME case such as US-AD Shrimp.

\subsection{Certain issues addressed by the US-AD Shrimp Panel}

\subsubsection{Factual background and the measures challenged}

$U S-A D$ Shrimp relates mainly to the WTO-consistency of final determinations made by the USDOC in the second and third administrative reviews regarding certain frozen and canned warm-water shrimp from, inter alia, Viet Nam, published on 1 February 2005. As already noted, in the original investigation and order, the USDOC treated Viet Nam as an NME. It further determined that it was impracticable to examine all Vietnamese exporters of shrimp, opting instead for a limited examination of four mandatory respondents accounting for the largest volume of exports during the period of investigation. Three of these mandatory respondents cooperated with the USDOC and each received individually calculated dumping margins ranging from $4.30 \%$ to $5.24 \%$ (i.e., Case C outcomes in Figure 1). These were used to calculate the 'all others' rate of $4.57 \%$, while the rate applied to all firms considered to be a part of the Viet Nam-wide NME was $25.76 \%$, a rate determined on an AFA basis (Case A outcomes). ${ }^{23}$

The second and third administrative reviews were the first such reviews relating to shrimp exports during a period subsequent to Viet Nam's WTO accession on 11 January 2007. The second administrative review, published on 9 September 2008 , included individual investigations of only two mandatory respondents, both of which revealed zero or negligible dumping margins. The USDOC applied either the same $4.57 \%$ 'all others' rate from the original investigation (for Case $\mathrm{F}$ outcomes) or the $25.76 \%$ Viet Nam-wide rate to firms not eligible for a 'separate rate' (i.e., Cases A, G, and E).

In the third administrative review, issued on 19 September 2009, the USDOC conducted individual investigations for only three mandatory respondents, once again finding only de minimis dumping margins of between $0.08 \%$ and $0.43 \%$. Non-mandatory respondents eligible for a separate rate received the much higher 
$4.57 \%$ 'all others' rate from the original investigation. The remaining firms were not considered eligible for a separate rate and therefore received the $25.76 \%$ Viet Nam-wide rate from the original investigation. ${ }^{24}$

With respect to these USDOC anti-dumping determinations, Viet Nam made four sets of claims relating to: the use of zeroing methodology, limited examination of selected mandatory respondents, application of the 'all others' rate to nonselected firms, and Viet Nam-wide entity rate. We discuss these claims in this order in the following pages, critiquing some of the hermeneutical choices made by the Panel.

\subsubsection{Zeroing methodologies in administrative reviews - the blurring of the lines} between 'as such', 'as applied', and 'continued use' complaints

Viet Nam attempted a general claim against the 'continued use of challenged practices', inspired by the relative success of a prior WTO case brought by the EU against a series of 18 US anti-dumping determinations involving zeroing. ${ }^{25}$ However, the US-AD Shrimp Panel rejected this claim as a preliminary matter upon the request of the US, finding that such 'continued', ongoing USDOC conduct had not been sufficiently identified by Viet Nam as a measure at issue in its request for a Panel, so that it lay outside the Panel's Terms of Reference. ${ }^{26}$ The Panel then exercised judicial economy with respect to the general question of whether a 'continued use of challenged practices' measure could be subject to challenge in the WTO, though citing the Appellate Body's acceptance of this possibility in the US-Continued Zeroing case. ${ }^{27}$

On the merits of Viet Nam's separate 'as applied' challenge to USDOC zeroing practice, the Panel followed prior jurisprudence ${ }^{28}$ and sided with Viet Nam and several Third Parties (India, Japan, Korea) in finding that 'simple zeroing' exercised by the USDOC in administrative reviews with respect to individually examined exporters was a violation of the 'fair comparison' requirement of Article 2.4 ADA. Indeed, this was found to be the case even when all individually calculated dumping margins were determined to be either zero or de minimis, and no duties were assessed and levied in practice. The US had argued that if dumping margins were

24 See ibid., paras. 7.26-7.27.

25 Appellate Body Report, United States-Continued Existence and Application of Zeroing Methodology, WT/DS350/AB/R, adopted 19 February 2009, DSR 2009:III, 1291 (hereafter USContinued Zeroing).

26 US-AD Shrimp, para. 7.68.

27 Ibid., para. 7.69.

28 See US-AD Shrimp, para. 7.91, referring to Appellate Body Report, United States - Sunset Review of Anti-Dumping Duties on Corrosion-Resistant Carbon Steel Flat Products from Japan, WT/DS244/ $\mathrm{AB} / \mathrm{R}$, adopted 9 January 2004; Appellate Body Report, United States - Final Dumping Determination on Softwood Lumber from Canada-Recourse to Article 21.5 of the DSU by Canada, WT/DS264/AB/RW, adopted 1 September 2006; and Appellate Body Report, United States - Measures Relating to Zeroing and Sunset Reviews, WT/DS322/AB/R, adopted 23 January 2007. 
zero or de minimis, one could not say that they had been inflated, but according to the Panel, '[e]ven in cases where no anti-dumping duties are assessed, the application of zeroing distorts the prices of certain export transactions, because export transactions made at prices above normal value are not considered at their real value'. ${ }^{29}$ This finding elevates the practice of zeroing, when challenged 'as applied', to one of a per se character, in the sense that the WTO-inconsistency of the practice is not dependent on its effects upon anti-dumping duties actually levied.

This per se 'as applied' finding can be difficult to logically distinguish from the subsequent finding by the Panel with respect to Viet Nam's claim that the US 'zeroing methodology' in periodic administrative reviews is a rule or norm of general and prospective application that is inconsistent with the ADA 'as such'.30 Viet Nam submitted this 'as such' claim, facing a higher threshold of proof because the challenged measure (zeroing methodology in periodic reviews) is not clearly expressed in the form of a written document. ${ }^{31}$ In order to confirm that USDOC adopts zeroing methodology as a general and prospective matter, the Panel relied upon evidence of the application of zeroing in practice, stating at one stage that the evidence shows that 'the USDOC will always apply zeroing' 32 and that the 'application of zeroing in administrative reviews extends well beyond the mere repetition of a practice in specific cases and rather substantiates Viet Nam's allegation that the USDOC maintains a deliberate policy to this effect'. ${ }^{33}$ This is in line with prior Appellate Body jurisprudence whereby evidence of the existence of a general and prospective rule or norm amenable to challenge 'as such', may include 'proof of [its] systematic application'. ${ }^{34}$

However, taken as a whole, the challenges against zeroing in US-AD Shrimp raise questions about the soundness of the analytical distinctions between the three separate claims made by Viet Nam, as assessed by the Panel: (1) the 'continued use of challenged practices' (rejected by the Panel on procedural grounds as lying outside its terms of reference); (2) the claim of 'as applied' inconsistency bearing in effect a per se character; and (3) the claim of 'as such' inconsistency, substantiated to large extent on the practice of zeroing 'as applied'. In US-Continued Zeroing, ${ }^{35}$ the Appellate Body opined that the distinction between 'as such' and 'as applied' is a 'heuristic device' that 'however useful, does not define exhaustively the types of measures that may be subject to challenge in WTO dispute settlement. In order to

29 See US-AD Shrimp, para. 7.93.

30 Ibid., para. 7.142.

31 The Appellate Body elaborated upon this higher standard of proof in Appellate Body Report, United States-Laws, Regulations and Methodology for Calculating Dumping Margins (Zeroing), WT/DS294/ AB/R, adopted 9 May 2006, and Corr.1, DSR 2006:II, 417 (hereafter US-Zeroing (EC)), para. 198.

32 See US-AD Shrimp, para. 7.117.

33 Ibid., para. 7.115.

34 See US-Zeroing (EC), para. 198.

35 US-Continued Zeroing, para. 179, supra at note 25. 
be susceptible to challenge, a measure need not fit squarely within one of these two categories, that is, either as a rule or norm of general and prospective application, or as an individual instance of the application of a rule or norm'. Thus, the 'continued use' of zeroing in successive proceedings resulting from 18 anti-dumping orders, was considered to be susceptible to challenge in a Panel procedure without being classified as either 'as such' or 'as applied'. The problem we note in US-AD Shrimp, however, is not the recognition of new categories of measures which may be challenged, but rather the interpretation of such categories in ways that blur the distinctions and create significant overlaps between them.

For present purposes, the importance of the Panel's findings of both 'as such' and 'as applied' ADA-inconsistency of USDOC zeroing methods in periodic administrative reviews lies in the role they returned to play in the evaluation of Viet Nam's claims regarding the validity of the 'all others' rate of anti-dumping duties applied to nonindividually assessed firms, as explained in Section 2.2.4.

\subsubsection{Limited examination of mandatory respondents - presumptions of statistical validity instead of substantive scrutiny}

USDOC's practice of limited examination is based on Article 6.10 ADA, which permits investigating authorities to diverge from the general rule of a comprehensive individual dumping-margin determination (established in the first sentence of that provision) '[i]n cases where the number of exporters, producers, importers or types of products involved is so large as to make such a determination impracticable' (as provided in the second sentence). Article 6.10 ADA states that the examination of dumping margins may then be limited:

either to a reasonable number of interested parties or products by using samples which are statistically valid on the basis of information available to the authorities at the time of the selection, or to the largest percentage of the volume of the exports from the country in question which can reasonably be investigated. (Emphases added.)

Article 6.10 ADA therefore attempts to strike a balance between the burden that comprehensive examinations place on investigating authorities' limited resources, on the one hand, and the implications of limited examination for the rights of exporting firms not individually investigated, on the other. It does so by: (a) restricting limited examinations to situations in which a comprehensive examination would be 'impracticable', as a threshold matter; and (b) demanding that limited examination be executed with respect to a sample of firms that conforms to alternative requirements of either statistical representativeness or to maximal coverage in terms of export volume.

In challenging the USDOC's practice of limited examination, one might therefore have expected Viet Nam to directly question the satisfaction by USDOC of either or both of these conditions, i.e., by claiming that a comprehensive examination of individual dumping margins was not impracticable, and/or by claiming that the 
sample of mandatory-response firms selected by USDOC was neither statistically valid nor of the largest export coverage still enabling reasonable investigation. Importantly, however, as noted by the US ${ }^{36}$ and emphasized by the Panel, this was not the case: 'Viet Nam is not challenging the USDOC's determination that it was "impracticable" to examine all known exporters and producers. Nor is Viet Nam challenging the number of exporters or producers which the USDOC included in its limited sample.' ${ }^{37}$ Indeed, the Panel expressly noted that it proceeded to evaluate Viet Nam's claims on the presumption that USDOC's limited examinations in the second and third administrative reviews were consistent with the requirements of Article 6.10 ADA, although it did not positively determine this. For the record, the Panel quoted (noncritically) the justification given by USDOC in its decisions to pursue only limited examination, in reference to the 'significant workload' imposed upon it by 'numerous concurrent antidumping proceedings', conducted under conditions of scarce resources. ${ }^{38}$ With respect to the sample quality and size employed in the limited examinations, the Panel merely noted, as a matter of fact, that in the second administrative review USDOC had examined two Vietnamese exporters accounting for $34 \%$ of total exports of relevant firms; and that in the third administrative review, it had selected three exporters of an unspecified share in total exports.

In short, absent a direct challenge by Viet Nam to the fulfillment by USDOC of the Article 6.10 ADA conditions for recourse to and conduct of limited examination, the Panel acted narrowly within its terms of reference and consequently adopted a fully deferential approach towards the USDOC's decisions in this respect, with no substantive scrutiny of those conditions. In Section 3, we provide an analysis of these questions from a statistical and economic perspective. Moreover, we will here briefly suggest that the Panel could have, and perhaps should have, addressed the substance of Article 6.10 ADA conditions for limited examination within the context of Viet Nam's claims as actually made (i.e., without a direct challenge).

Viet Nam claimed that the way USDOC applies limited examination under Article 6.10 ADA led to violations of the substantive rights of nonselected firms derived from other provisions of the ADA, namely under Article 9.3 (restriction of anti-dumping duties to margins calculated under Article 2 ADA), Article 11.1 (imposition of anti-dumping only when necessary to counteract dumping causing injury), and Article 11.3 ADA (termination of definitive anti-dumping duties after five years subject to 'sunset' review). Viet Nam was in essence arguing that because these provisions implicitly require findings to be made for individual firms (a point that was itself contested by the US), repeated limited examination that necessarily 
entails exclusion of nonmandatory respondent firms constitutes a denial of their substantive rights.

This claim can technically be reduced to the question of the relationship between the rule of comprehensive individual examination established in the first sentence of Article 6.10 ADA, the exception of limited examination allowed by the second sentence of that provision, and the substantive rights established in other ADA provisions. The Panel followed some of the parties' arguments in this vein and pursued this line of analysis, which leads to a dichotomous logical choice between two interpretative extremes. Either, as Viet Nam argued, the Article 6.10 ADA allowance for limited examination cannot release the investigating authority from its substantive obligations towards nonselected firms under Articles 9 and 11 ADA, because such an interpretation of the exception would render the rule and those additional provisions meaningless; or, as argued by the US, the exception trumps those substantive individual-firm rights (to the extent that they exist under Articles 9 and 11 ADA), and any other interpretation would render the Article 6.10 ADA second-sentence exception meaningless. Between these two possibilities, the Panel chose to grant effect to the exception, rejecting Viet Nam's claim. ${ }^{39}$

We believe another, more nuanced approach could have been adopted, one that better takes into account the role of Article 6.10 ADA in striking the balance we have alluded to above, between investigative burdens, on the one hand, and individual-firm procedural and substantive rights in anti-dumping investigations. This balance is first and foremost regulated by the conditions of impracticability and statistical validity or reasonable sample size established by the second sentence of Article 6.10 ADA with respect to the exercise of limited examination. Indeed, at one end of the spectrum, if simply none of these conditions were fulfilled, limited examination would certainly be ADA-inconsistent and all individual-firm rights would ipso facto remain intact. At the other end of the spectrum, if both conditions were perfectly fulfilled - and in particular the requirements of sample quality and size - it could be said that the exercise of individual-firm rights would be redundant and unduly burdensome.

However, given the relative fluidity of the tests of impracticability and sampling, there may well be intermediate situations in which imperfect sampling, (imperfect, either because it was not entirely justified, or because it was not properly conducted) would cause a disproportionate infringement of at least some excluded firms' rights. For example, if the sample included only large firms, to the exclusion of all small firms - whose capacity to engage in dumping can be very different - and could only be rectified by individual examination. ${ }^{40} \mathrm{We}$ analyse the issue of

39 Ibid., para. 7.167.

40 To be sure, individual examination in such circumstances could be achieved through voluntary responses by nonselected firms, under the terms of Article 6.10.2 ADA. However, as we have seen in Section 2.1, in a USDOC NME investigation, a voluntary response could at best result in the responding 
appropriate sampling in more detail in Section 3, but the point made here is that the question raised by Viet Nam's Article 6.10 ADA claim could not have been fully examined by the Panel in isolation from the evaluation of the degree of conformity of USDOC limited examination with the conditions of the second sentence of Article 6.10 ADA.

Furthermore, although (as already noted) no violation of Article 6.10 ADA was claimed by Viet Nam, the arguments of both parties to the dispute referred to the balancing role of Article 6.10 ADA and the fulfilment of its conditions. Viet Nam argued that 'the USDOC made no effort in the proceedings at issue to balance its right to conduct limited examinations with the interests and rights of Vietnamese respondents to have duties assessed based on individual margins and to obtain a company-specific review in order to demonstrate the absence of dumping' ${ }^{41}$ The US stressed that Article 6.10 ADA permits the investigating authority to limit its examination 'whenever the conditions for doing so are met, i.e., where the number of exporters/producers makes determinations of individual margins for all exporters/producers "impracticable", ${ }^{42}$ Nevertheless, the Panel limited its finding to stating that 'the use of limited examinations is governed exclusively by the second sentence of Article 6.10', not only refraining from evaluating the fulfilment of those conditions, but also effectively depriving that provision of its broader context within the ADA and ignoring the impact of limited examination upon individual-firm rights.

Viet Nam's second claim on the conduct of limited examination related to USDOC's treatment of nonmandatory response firms who had volunteered information. Article 6.10.2 ADA requires investigating authorities to assess individual dumping margins for such nonmandatory respondents, except 'where the number of exporters or producers is so large that individual examinations would be unduly burdensome to the authorities and prevent the timely completion of the investigation'. The final sentence of Article 6.10.2 ADA further provides that '[v]oluntary responses shall not be discouraged'. The provision should be understood as a partial response to the potential infringement of individual-firm rights as a result of exclusion from limited examination, and as an extension of the balance between investigative burden and exporting firms' rights, as discussed above. Thus, a firm fearing that the dumping margins calculated on the basis of mandatory responses would be higher than its individual dumping margin (which may in fact be de minimis, zero, or negative) may voluntarily provide information on its sales, and benefit from individual assessment. Only if the investigating authority is faced with such a large number of responses as to defeat the purpose of

firm receiving the 'all others' rate, rather than the 'entity-wide' rate; and as we shall see below, the US-AD Shrimp Panel rejected Viet Nam's claims regarding the application of Article 6.10.2 ADA.

41 See US-AD Shrimp, para. 7.147.

42 Ibid., para. 7.158. 
limited examination, may requests for individual assessment based on sufficient information be denied.

Viet Nam argued that USDOC treated submissions of voluntary responses in reliance upon its original evaluation of the reasonable scope of the investigation under Article 6.10 ADA, where it should have separately determined the number of additional voluntary responses that its investigative capacities could absorb; USDOC policy in this respect provided no flexibility towards nonmandatory respondents and was therefore tantamount to a discouragement of voluntary submissions. ${ }^{43}$ In its defence, the US made the factual argument whereby in practice no full voluntary submissions were received from nonmandatory respondents in either the second or third administrative review. It further denied that any action or indeed inaction on its part had constituted a discouragement of voluntary responses. ${ }^{44}$

The Panel's task with respect to the Article 6.10.2 ADA claims by Viet Nam was on its face relatively simple. Indeed, because no voluntary responses had been submitted, the Panel found that obligations under the first sentence of Article 6.10.2 ADA were not 'triggered'. ${ }^{45}$ No persuasive evidence of 'discouragement' of voluntary submissions had been presented by Viet Nam. The Panel therefore rejected Viet Nam's claims. One point in the Panel's reasoning merits further scrutiny, however, because it bears upon the relationship between the mandatory respondent sample selection in limited examination under Article 6.10 ADA, on the one hand, and the scope for additional voluntary responses under Article 6.10.2 ADA, on the other. Viet Nam argued that USDOC's 'explicit statement that it cannot and will not examine more than the identified number of companies will of course dissuade companies from seeking examination on a voluntary respondent basis' ${ }^{46}$ This argument, too, was rejected by the Panel, relying on the legitimacy of the USDOC decision to limit its examination, a decision which in itself could not, in its view, constitute evidence of a discouragement of voluntary responses. Here again we observe that the conformity of USDOC's sample of firms selected for limited examination with the requirements of Article 6.10 ADA was assumed by the Panel rather than determined on its merits. An examination of the quality and size of the sample could have led to the conclusion that it was overly restrictive or unrepresentative. While the most obvious remedy for such a finding would have been an expansion of the group of mandatory respondents, we contend that such an unjustifiably narrow sample could also lead to an indirect 'chilling effect' on firms not included in the original sample. We note again that we will expand on the statistical analysis of limited-examination sampling in Section 3.

43 See ibid., paras. 7.172-7.175.

44 See ibid., paras. 7.176-7.178.

45 See ibid., para. 7.183 .

46 See ibid., para. 7.185. 


\subsubsection{The application of the 'all others' rate to nonselected firms}

Viet Nam also made claims regarding the 'all others' rate applied by USDOC in the second and third administrative reviews, i.e., the rate applied to non-Mandatory respondents who had requested a separate rate and provided information (Case $\mathrm{F}$ in Figure 1). Notably, in the second and third administrative reviews, the individual rates calculated for the mandatory respondents were ultimately all de minimis - less than $0.5 \%$. Nevertheless, in these reviews USDOC chose to apply the $4.57 \%$ rate derived from the original investigation (applied as well in the first administrative review) to most nonselected Vietnamese firms, considering this approach to be 'a reasonable method which is reflective of the range of commercial behaviour demonstrated by exporters of the subject merchandise during a very recent period' ${ }^{47}$

Under the terms of Article 9.4 ADA, the 'all others' rate shall not exceed 'the weighted average margin of dumping established with respect to the selected exporters or producer', excluding any zero and de minimis margins and margins based on AFA. The question therefore arises, whether the 'all others' rate selected by USDOC was not in excess of the relevant average margin. The determination of this margin is in itself a matter of uncertainty, when all applicable dumping margins are zero or considered de minimis and hence excluded from the calculation. It would appear to be unclear how the 'all others' margin can be calculated when all individual margins are excluded, and the Appellate Body has indeed characterized this situation as a 'lacuna'. ${ }^{48}$ We will analyze this issue in more detail in Section 4. However, it is important to note that the question was not directly tackled by the Panel. The main claim addressed by the Panel was that the 'all others' rate was determined on the basis of dumping margins calculated with the use of zeroing. This claim was somewhat complicated by the US assertion that ADA disciplines did not in any event apply to this rate because USDOC had simply continued to apply the 'all others' rate calculated prior to Viet Nam's accession to the WTO. The intertemporal argument was rejected by the Panel, however, because the evidence showed that USDOC had made 'a new and distinct' determination of the 'all others' rate in each administrative review, subsequent to Viet Nam's WTO accession. ${ }^{49}$ Because the use of zeroing in the calculation of dumping margins for mandatory respondents had already been factually established, and the Panel considered it to be inconsistent with Article 9.4 ADA to determine the maximum allowable 'all others' rate on the basis of dumping margins calculated with the use of zeroing, Viet Nam's claim regarding the 'all others' rate was accepted by the Panel. Additional claims by Viet Nam were not addressed by the Panel on the basis of 'judicial economy'.50

47 See ibid., paras. 7.197-7.198.

48 See US-Hot-Rolled Steel, supra at note 11.

49 See US-AD Shrimp, paras. 7.221-7.223.

50 See ibid., para. 7.229. 


\subsubsection{The application of the 'Viet Nam-Wide Entity' rate}

Finally, Viet Nam made claims regarding the rate of antidumping duties levied upon shrimp exporters considered to be part of the 'Viet Nam-wide' NME entity, assimilated to the very high 'AFA' rate (cases $E$ and $G$ in Figure 1) rather than the 'all others' rate. Here, too, with all individually calculated margins being either zero or de minimis, the US argued that Article 9.4 placed no constraints on the nature of a maximum allowable rate, and that it therefore could not be in violation of Article 9.4 ADA. ${ }^{51}$ The Panel did not accept this argument, finding instead that nothing in Article 9.4 ADA, lacuna notwithstanding, sanctioned a separate rate for nonindividually assessed firms that was not the 'all others' rate, and that USDOC unjustifiably applied a higher AFA rate to numerous Vietnamese firms. US arguments whereby the AFA rate was applied due to lack of cooperation by firms were rejected, inter alia due to strong indications that the AFA rate would have been employed by USDOC in any case. ${ }^{52}$

We turn now to a more detailed analysis of the two main issues raised in US-AD Shrimp, in our view: the sampling of firms for the purposes of limited examination, and the treatment of the so-called lacuna in Article 9.4 ADA.

\section{Statistical sampling in anti-dumping investigations and reviews}

\subsection{Dumping investigations: divergence from the ideal}

The most interesting issues underlying US-AD Shrimp revolve around sampleselection bias in dumping investigations. The procedures laid out above and summarized in Figure 1, and the practices challenged in the dispute as just described, make clear that the USDOC only calculates individual dumping margins on a small subset of foreign exporters. The USDOC uses the results from this small sample of investigated firms to calculate the 'all others' rate for nonsampled firms. The culling process to identify the particular group of enterprises included in the sample as mandatory respondents, to assess whether mandatory respondents have been cooperative 'enough', and to determine which firms are eligible for separate rates in an NME investigation, all raise substantive issues about how representative this sample might be. These procedures are especially important for NME exporters since the best rate that nonsampled firms may receive is the 'all others' rate.

This process can easily lead to sampling bias for at least two reasons. First, the firms that are used to calculate the 'all others' rate are chosen by the USDOC neither randomly nor with statistical representativeness in mind. Second, the information required by the USDOC is costly to collect so that some foreign firms, 
particularly small ones, may decide not to cooperate on a simple cost - benefit basis.

One of the basic principles of the ADA is that dumping margins are based on the pricing decisions of individual foreign exporters. As mentioned above, Article 6.10 ADA requires that 'authorities shall, as a rule, determine an individual margin of dumping for each known exporter'. The accurate calculation of such margins necessarily demands important data that can be acquired only from foreign firms themselves.

In an ideal world, the investigating authority would obtain full information at no cost with respect to each foreign firm exporting the product into the domestic market. The authority would institute procedures that were simple and each foreign firm would cooperate fully with the authority in a timely fashion. Such an ideal outcome would result in every exporter being treated on the basis of its individual data.

Commercial and legal realities diverge importantly from this ideal world. First, information frequently is costly to obtain and collect, both for the investigating authority and for responding foreign firms. Second, foreign firms cannot be compelled to respond to inquiries from domestic investigators about activities taking place outside the authorities' jurisdiction. Third, the investigating agency cannot be forced to use information provided by every foreign firm. This combination of costly information and noncompulsion means that there are frequent instances where only a portion of the underlying commercial reality is used when assessing dumping margins and the resulting duties. Finally, in the case of an NME like Viet Nam, the domestic investigating authority must determine whether price information provided by a particular exporter can be used to calculate dumping margins at all, i.e., whether a particular foreign firm is eligible for a 'separate rate'.

Let us turn first to the problems faced by the USDOC when there might be many exporters subject to a dumping investigation, with consequent high information and administrative costs. These issues are relevant for both NME and marketeconomy cases.

The second sentence of Article 6.10 ADA explicitly allows for investigating authorities to limit their examination in such instances to a 'reasonable number' of exporters that either: (a) represents 'the largest percentage of the exports ... which can reasonably be investigated', or (b) is 'statistically valid.' The results from these investigations can then be used to determine the 'all others' rate applied to nonsampled firms. As a general principle, the US has chosen the former of these two approaches.

The underlying idea behind the second sentence of Article 6.10 ADA is that the data used to calculate the 'all others' rate should be representative. On the one hand, sampling the 'largest percent' of exports is an implicit attempt to obtain information that reflects the broad realities of the market. While the ADA does not specify a particular percentage that would satisfy the criteria, the intention that it be 
large enough to approximate broader market conditions is clear. The second option of a 'statistically valid' sample makes this even more explicit. And since these are alternatives, one might reasonably expect that they have the same intent - to collect information about some firms that can be applied appropriately to exporters not surveyed by domestic authorities.

The number of firms that can be included under either approach of Article 6.10 ADA depends on the administrative burden on the investigating authority. However, it is important to note that the extent of these burdens is largely determined by the particular procedures adopted by the investigators themselves. The USDOC could streamline the process so that its self-imposed burdens could be lowered and it could investigate many more foreign exporters. For example, the US choice of using a retrospective system (i.e., where the final anti-dumping duties are based on pricing behavior over the previous year) increases the costs for USDOC to calculate dumping margins (and for foreign firms to provide that information) since data must be collected throughout each year.

In any event, the high cost of conducting an investigation has meant in practice that the USDOC only investigates a small number of firms. (For example, recall that only two Vietnamese firms were included in the second administrative review.) The USDOC must choose which specific firms to include in its sample. As noted above, standard USDOC practice is first to obtain export quantity and value data from as many exporters as possible. The USDOC then chooses to send detailed questionnaires only to a limited group of the target country's very largest exporters to the US for the actual dumping investigations. These firms are chosen without consultation with exporters. ${ }^{53}$ Moreover, as we have emphasized above, the USDOC approach to only consider a limited sample of the very largest firms and USDOC's approach to selecting these firms were not in dispute in the case. There is, however, nothing to suggest that considering only the largest firms is an appropriate methodology for the 'all others' rate from a statistical standpoint though it arguably is consistent with the Article 6.10 ADA provision allowing limited examination if it focuses on a 'reasonable' number of firms representing the 'largest' export percentage.

Indeed, there may be something systematically different about the very largest firms that make them quite distinct from other firms in the overall population. Perhaps the larger firms are more likely to price aggressively or smaller firms have higher costs, both of which could alter the dumping margins in a systematic way. ${ }^{54}$

53 Article 6.10.1 ADA notes that '[a]ny selection of exporters, producers, importers or types of products made under this paragraph shall preferably be chosen in consultation with and with the consent of the exporters, producers, or importers concerned' (emphasis added). This 'preference' is not reflected in USDOC procedures.

54 Recent international-trade research has focused increasingly on heterogeneity among firms. Two classic studies include Melitz (2003) and Helpman et al. (2004). 
A second complication of sample selection arises because some foreign firms may refuse to provide information about their pricing and costs. An investigating authority thereby might be stymied while trying to assess a particular dumping margin. In order to encourage cooperation, the ADA included a provision to use other information for assessing the dumping margins of nonresponsive foreign firms, that can even be seen as punitive or coercive in nature - the 'adverse facts available' AFA route. ${ }^{55}$ In practice, AFA often has consisted of the pricing allegations lodged by domestic petitioners, who would likely claim that they faced very high dumping margins. Indeed, an exporter might not have an incentive to cooperate and provide actual data if it is chosen for the sample as long as the AFA allegations were lower than its actual dumping margin. ${ }^{56}$

Moreover, the use of AFA includes yet another source of potential sampleselection bias that muddies the waters of assessing 'average' dumping margins for use in the 'all others' rate. First, the foreign firm's choice of whether or not to provide data is not as simple as we have just suggested. Collecting information that satisfies the domestic agency is costly for the exporting firm. In addition, domestic investigators have at least some discretion about how burdensome that process is for firms and thereby potentially could influence which exporters ultimately choose to cooperate. They also have the final say as to whether foreign firms have been cooperative 'enough' to avoid necessarily high AFA margins. The upshot is that those firms who choose to cooperate may not be like other nonsampled firms. On the one hand, they might have higher dumping margins than even the domestic firms allege, making AFA a relatively attractive proposition. On the other hand, they might be discouraged from cooperating by excessively burdensome procedures established by the investigating agency itself.

\subsection{Selecting a more representative sample}

The 'statistically valid' approach contained in the second sentence of Article 6.10 ADA would be more attractive in principle than simply examining a small number of the largest firms. When choosing a sample that is statistically valid, that group should reflect the different types of individual firms in the underlying population. In addition, the choice of investigated firms within representative subgroups should be random. The analyst should also weigh the sampling outcomes by their share in the overall population. ${ }^{57}$ For example, if 'large' firms represent half of exports, then no more than half of the weighted-average 'all others' dumping margin should be based on such larger firms.

55 See Article 6.8 and Annex II ADA.

56 For a discussion about foreign firms' decision to cooperate in anti-dumping investigations see Moore (2005) and Moore and Fox (2010).

57 Public-opinion polls routinely take such considerations into account. For example, suppose a country's citizens are $50 \%$ female. If a particular random sample were $75 \%$ male, then one would want to adjust the weights on the outcomes so that females were not underrepresented in the final results. 
Another way to avoid the problems of using unrepresentative data would be to allow nonsampled firms to volunteer information that can be used to calculate a firm-specific rate and contribute to the assessment of the 'all others' rate. This of course increases the administrative burdens on domestic investigators, but it also raises a further complication. In particular, which type of foreign firm would more likely be asked to submit such data? Any firm with dumping margins below the 'all others' rate based upon the dumping margins of the cooperating mandatory respondents would clearly have an incentive to provide such data. Exporters with higher margins would not volunteer information but could potentially benefit from self-reporting low-margin firms if their data were added to the 'all others' calculation.

The ADA embodies many of these considerations in the final text. As noted above, Article 6.10 ADA allows domestic agencies to investigate only some firms, implicitly because of the practical costs of investigating all exporters. The ADA also allows individual nonsampled exporters to offer information voluntarily to provide information but still nods in the direction of domestic-agency investigation costs by allowing it to ignore this information if it is not 'practicable' to conduct the investigation. But while the ADA allows for individually investigated exporters to receive their own firm-specific dumping margins, it does exclude AFA and less than de minimis (including zero) margins in the calculation of the 'all others' rate, implicitly because these are, by definition, considered nonrepresentative of the underlying population of exporters. In passing, we would note that the exclusion of AFA-based margins is justified in this respect, because such margins are not based on full data. The exclusion from the 'all others' rate of zero and de minimis margins based on individual-firm investigations is less justifiable from a statistical viewpoint, though this is allowed explicitly in Article 9.4 ADA.

A final complication in NME cases is that the USDOC determines which firms are eligible for a 'separate rate' and not subject to the entity-wide rate, which is usually based on AFA. The USDOC determines which of the mandatory respondents are eligible for the separate rate and therefore included in the sample of individually investigated firms. This means that domestic investigators have additional leeway about which particular firms are included in the sample in an NME case.

In addition, nonmandatory respondents in NME cases may ask for a separate rate (and to be eligible for the 'all others' rate) but the USDOC makes the decision whether firms are eligible. These provisions increase the discretion of the USDOC and add another potential layer of sample-selection bias. In addition, these nonmandatory respondents deemed eligible for a separate rate can do no better than receive the (potentially flawed) 'all others' rate; the USDOC normally does not conduct a new investigation for such firms. This raises the stakes in NME cases about the appropriate methodology for sampling when calculating 'all others' rates. 
Table 1 (a). Hypothetical original non-market economy investigation

\begin{tabular}{lccccccc}
\hline \hline & Sales & $\begin{array}{c}\text { Actual } \\
\text { dumping } \\
\text { margin }\end{array}$ & $\begin{array}{c}\text { Government } \\
\text { controlled }\end{array}$ & $\begin{array}{c}\text { Cooperate } \\
\text { with } \\
\text { USDOC }\end{array}$ & $\begin{array}{c}\text { Margin } \\
\text { calculated by } \\
\text { USDOC }\end{array}$ & $\begin{array}{c}\text { Final } \\
\text { margin }\end{array}$ & $\begin{array}{c}\text { Mandatory } \\
\text { response } \\
\text { firm }\end{array}$ \\
\hline Firm 1 & 100 & 15 & Yes & NA & & $10^{\mathrm{a}}$ & Yes \\
Firm 2 & 100 & 8 & Yes & NA & & $10^{\mathrm{a}}$ & Yes \\
Firm 3 & 100 & 4 & No & Yes & 4 & 4 & Yes \\
Firm 4 & 100 & 1 & No & Yes & 0 & 0 & Yes \\
Firm 5 & 50 & 8 & No & NA & & $10^{\mathrm{a}}$ & No \\
Firm 6 & 50 & 0 & No & NA & & $10^{\mathrm{a}}$ & No \\
\hline \hline
\end{tabular}

Notes: ' 'Entity-wide rate' (normally equal to 'adverse facts available' (AFA) rate) equal to $10 \%$ by assumption.

Table 1 (b). Hypothetical administrative review non-market economy investigation

\begin{tabular}{lccccccc}
\hline \hline & $\begin{array}{c}\text { Actual } \\
\text { dumping } \\
\text { margin }\end{array}$ & $\begin{array}{c}\text { Government } \\
\text { Controlled }\end{array}$ & $\begin{array}{c}\text { Cooperate } \\
\text { with } \\
\text { USDOC }\end{array}$ & $\begin{array}{c}\text { Margin } \\
\text { calculated by } \\
\text { USDOC }\end{array}$ & $\begin{array}{c}\text { Final } \\
\text { margin }\end{array}$ & $\begin{array}{c}\text { Figure 1 } \\
\text { outcome }\end{array}$ \\
\hline Firm 1 & 100 & 15 & Yes & NA & & $10^{\text {a }}$ & Case A \\
Firm 2 & 100 & 8 & Yes & NA & & $10^{\text {a }}$ & Case A \\
Firm 3 & 100 & 0 & No & Yes & 0 & 0 & Case B \\
Firm 4 & 100 & 0 & No & Yes & 0 & 0 & Case B \\
Firm 5 & 50 & 0 & No & NA & & $10^{\text {a }}$ & Case G \\
Firm 6 & 50 & 0 & No & NA & & $?$ & Case F \\
\hline \hline
\end{tabular}

Notes: ${ }^{\text {a }}$ Entity-wide rate' (= 'adverse facts available' (AFA) rate).

\subsection{A bypothetical numerical example}

In Table 1, we also include hypothetical results of an original investigation and administrative review in an NME case such as US-AD Shrimp.

We assume that Firms 1 through 4 are 'large' firms that each export 100 units to the US. Firms 5 and 6 are small and export only 50 units. In the ideal situation, Firms 4 and 6 would not face anti-dumping duties in the original investigation because of either zero or de minimis margins; all other firms would face antidumping duties ranging from $4 \%$ to $15 \%$.

In panel (a) of Table 1, we include assumptions about the original investigation, including whether a foreign firm is eligible for a separate rate under provisions of US law, either as a mandatory respondent, or as a firm voluntarily cooperating with the investigation. Consistent with the discussion above, we assume that administrative costs preclude the USDOC from investigating all firms. In addition, we assume that Firms 1 and 2 are government-controlled exporters. 
We assume that Firms 1 through 4 were mandatory respondents. Firms 1 and 2 did not cooperate in the original investigation so they receive an entity-wide AFA rate, assumed for concreteness to equal 10\%. Firms 3 and 4, having cooperated with the investigation, are eligible for a separate rate, with a de minimis rate for Firm 4. Firms 5 and 6 did not ask for a separate rate under NME procedures and so are assessed the entity-wide rate of $10 \%$.

In panel (b) of Table 1, we illustrate one possible outcome in an administrative review in an NME context similar to the issues faced in US-AD Shrimp. We have assumed that (government-controlled) Firms 1 and 2 do not change their pricing decisions after the original investigation and so continue to engage in dumping at the original rate. All other firms adjust their pricing decisions so that they are no longer dumping. Suppose that Firms 3 and 4 are those chosen by USDOC for investigation in the administrative review, since they are the two largest exporters qualifying for a separate rate as would be the case under USDOC normal procedures. We assume that Firm 5 has not asked for a separate-rate investigation in the administrative review so that it continues to receive the AFA entity-wide rate.

One of the core issues of US-AD Shrimp is illustrated by the situation facing Firm 6. If Firm 6 does not request a separate-rate determination under USDOC NME procedures, then it simply receives the EWR of $10 \%$ (based on AFA) and there are no further decisional complications.

However, if Firm 6 does ask for a separate rate, and qualifies in the judgment of the USDOC, then the USDOC faces a problem. In this particular example (which mirrors the facts of $U S-A D$ Shrimp), there are no outcomes that normally would be used by the USDOC to calculate an 'all others' rate, i.e., Firms 3 and 4 have zero dumping margins (Case B outcomes in Figure 1) and Firms 1, 2, and 5 have rates based on AFA (Cases A and G outcomes in Figure 1). There are no Case C outcomes on which to base the 'all others' rate in this NME administrative review using standard USDOC procedures. The question becomes what would be a reasonable and statistically representative approach for the 'all others' rate for Firm 6.

One approach, and which in fact was used in the second and third administrative reviews of US-AD Shrimp, would be to look back to the 'all others' rate from the original investigation ( $4 \%$ in Table $1(\mathrm{a}))$. This has clear statistical problems. First, the margin is based on a single observation for a larger exporter. Second, the margin is calculated based on the market conditions in an earlier period. One might certainly expect that the behavior of exporters would be influenced by the imposition of anti-dumping duties and overall market conditions such as changing demand and supply conditions, etc. ${ }^{58}$

58 A perverse result of this approach taken by USDOC is that Firm 6 may face higher margins if other firms eliminate their own dumping. Suppose, instead of eliminating dumping, Firm 3 lowers its actual dumping margin during the administrative-review period to $1 \%$. Firm 6 then would face a $1 \%$ margin since there is now an observation that meets the standard NME 'all others' rate procedures in administrative reviews. 
Alternatively, this problem could be solved by USDOC requesting that Firm 6 provide input quantity data so the agency could calculate a true separate rate as would be done for a Case $\mathrm{C}$ type firm in Figure 1. This would allow the outcomes for Firm 6 to be based on its own contemporaneous economic realities. However, it is important to note a potential downside of this effort to accommodate Firm 6. Suppose that this is a small firm that would find it difficult to collect the requisite information for its own investigation by the USDOC. If these costs are so high that it chooses not to cooperate, it will now face the AFA rates (of $10 \%$ in this example) rather than the 'all others' rate of $4 \%$ from the original investigation. ${ }^{59}$

If investigators decide not to ask for relevant information from Firm 6, then at least one would hope that they adopt a procedure that would approximate a sample that yielded results plausibly 'representative' of Firm 6 behavior. For example, they could look to recently acquired information from exporters during the period of investigation, which would be relevant information about recent Firm 6 behavior. Indeed, USDOC would have on hand the results of investigations from Firms 3 and 4, which could be used to establish the separate rate for Firm 6, which in this case would be a margin of $0 \%$.

This discussion makes clear that many of the underlying issues in US-AD Shrimp transcend the problems of this particular dispute (and importantly, are unrelated to zeroing methodologies). Domestic investigators have the qualified right under the ADA to limit the number of exporters that are queried for firm-specific data used to calculate dumping margins. In US practice, this means that other exporters, even those willing to voluntarily provide information of their own to investigators, will face potentially unrepresentative 'all others' dumping rates. This problem is exacerbated by a US tendency, evident in all stages of the investigations and reviews in the present case, to query only the largest exporting firms, which could have very different economic characteristics than nonsampled firms.

A useful reform would be for the US to simplify the process of calculating dumping margins. This would not only lower the administrative costs that the USDOC would face but would increase the number of foreign firms that could potentially provide information that would result in more accurate dumping margins. An increase in the number of investigated firms would also reduce the chances of the USDOC facing the awkward circumstance that arose during the administrative reviews that triggered the US-AD Shrimp dispute, where there were no nonzero, de minimis, or AFA margins on which to base the 'all others' rate. In short, the USDOC has at its disposal the means - and methods, should it elect to employ them - to minimize the use of unrepresentative samples that both burden foreign exporters and risk nonconformity with the ADA.

59 Note that the facts of US-AD Shrimp are even more extreme. As noted above, the original 'all others' rate was $4.57 \%$ compared to $25.76 \%$ for the AFA rate. 
Furthermore, we believe that it is possible and indeed desirable to incorporate the insights of the above statistical analysis into the legal principles of Article 6.10 ADA. It is therefore to some extent unfortunate that Viet Nam, in this dispute, did not directly challenge USDOC's sampling practices in its investigations and administrative reviews, and that the Panel did not see fit to address the fundamental question of whether USDOC's limited examination satisfied the conditions set out in Article 6.10 ADA, employing, for example, the logic of legal interpretation suggested in Section 2.2.3. It remains to be seen to what extent the issue of sampling will be dealt with in the recently launched follow-up dispute; in the request for consultations, Viet Nam specifically mentioned 'the practice of limiting the number of respondents selected for individual examination to only a small fraction of the total number of companies seeking individual review', as one of the measures it intends to challenge. ${ }^{60}$

\section{Dealing with 'Lacuna' in Article 9.4 ADA}

We now turn to discuss the supplementary problem of calculating an 'all others' rate under special circumstances such as posed in US-AD Shrimp. As already noted, under Article 9.4 ADA, the 'all others' rate shall not exceed 'the weighted average margin of dumping established with respect to the selected exporters or producers', excluding any zero and de minimis margins and margins based on AFA. How then can such a ceiling on the 'all others' rate be calculated, when all the individually calculated margins are zero, de minimis, or AFA? In mathematical terms, this would mean calculating the weighted average of an 'empty set', and the average of an empty set is not well-defined mathematically. Indeed, it can be characterized as an empty set in itself. The ceiling for the 'all others' rate would therefore be a nonexistent figure. It would thus appear that in these circumstances Article 9.4 ADA does not in itself define a ceiling for the 'all others' rate. However, from a mathematical perspective, the absence of a defined ceiling is not the same as an unlimited ceiling of infinity.

In US-Hot-Rolled Steel, the AB took note of this problem by stating that Article 9.4 ADA presented a lacuna:

This lacuna arises because, while Article 9.4 prohibits the use of certain margins in the calculation of the ceiling for the 'all others' rate, it does not expressly address the issue of how that ceiling should be calculated in the event that all margins are to be excluded from the calculation, under the prohibitions. (Original emphases). ${ }^{61}$

60 See United States-Anti-Dumping Measures on Certain Shrimp from Viet Nam-Request for Consultations by Viet Nam, supra at note 14.

61 See US-Hot-Rolled Steel, at para. 126, supra at note 11. 
The $\mathrm{AB}$ then did not deem it necessary to fill this lacuna, in the circumstances that arose in that case.

This celebrated reference to a lacuna in Article 9.4 ADA is in some respects unfortunate. Article 9.4 ADA, in our view, does not represent a lacuna in any meaningful respect. The fact that Article 9.4 ADA produces an 'empty set' or undefined figure for the establishment of a specific ceiling does not mean that adjudicators are faced with a lacuna. A lacuna would emerge only if there were no legal (WTO) rules that could be applied to the facts at hand. Clearly, this is not the case: the imposition of anti-dumping duties at an 'all others' rate is still subject to the more general rules of the ADA, even in the absence of a calculable ceiling. We agree with previous commentators on US-Hot-Rolled Steel (Pauwelyn, 2003; van Damme, 2009) that so long as a measure is subject to some WTO law and within the jurisdiction of the WTO dispute-settlement system, there is no lacuna, and no scope for a non liquet (a decision not to decide) on such grounds. This determinedly positivistic position conforms with more general understandings of the limited potential for lacunae in international law (Lauterpacht, 1958; Stone, 1959; Weil, 1997). It would also appear to be the position adopted by WTO adjudicators in subsequent cases, including US-AD Shrimp.

Article 9.4 ADA is a specific provision applying in the exceptional circumstances of limited examination. There is no reason to assume that when Article 9.4 ADA itself proves inoperable, the broader context of the ADA does not have purchase, both as applicable law and as interpretative context. In a subsequent case, US-Zeroing (EC) (Article 21.5-EC), ${ }^{62}$ the Appellate Body acknowledged this by stating that:

[T] he fact that all margins of dumping for the investigated exporters fall within one of the categories that Article 9.4 directs investigating authorities to disregard, for purposes of that paragraph, does not imply that the investigating authorities' discretion to apply duties on non-investigated exporters is unbounded. The lacuna that the Appellate Body recognized to exist in Article 9.4 is one of a specific method. Thus, the absence of guidance in Article 9.4 on what particular methodology to follow does not imply an absence of any obligation with respect to the 'all others' rate applicable to non-investigated exporters where all margins of dumping for the investigated exporters are either zero, de minimis, or based on facts available. ${ }^{63}$

In this case as well, the $\mathrm{AB}$ exercised a form of judicial economy, relieving it of the need to establish precisely what the methods for and boundaries of calculating the 'all others' rate in these circumstances are. However, it was unequivocal in

62 See Appellate Body Report, United States-Laws, Regulations and Methodology for Calculating Dumping Margins (Zeroing)-Recourse to Article 21.5 of the DSU by the European Communities, WT/DS294/AB/RW and Corr.1, adopted 11 June 2009, DSR 2009:VII, 2911.

63 Ibid., para. 453. 
establishing that the calculation of the 'all others' rate remained subject to ADA disciplines, the specific 'lacuna' of Article 9.4 ADA notwithstanding.

In US-AD Shrimp, the Panel followed the AB's guidance, interpreting it 'to mean that if an investigating authority limits its investigation and applies an "all others" rate to non-selected exporters, its discretion in doing so is not unlimited'. From this the Panel deducted that 'the margins of dumping which are used to establish the maximum allowable "all others" rate must be ones which, at the time the "all others" rate is applied, conform to the disciplines of the Agreement'. ${ }^{64}$ Hence the Panel's conclusion that an 'all others' rate based on margins calculated with the use of zeroing methodology were ADA-inconsistent.

What are the implications of these interpretations of Article 9.4 ADAovercoming its nature as an erstwhile lacuna-for the future application of the provision? What would be the ground rules if the margins had not been calculated using zeroing? In other words, if circumstances such as those that arose in US-AD Shrimp occur again, what are the bounds of calculation of an 'all others' rate in the face of an 'empty set'? We suggest that this question should best be addressed taking Article 6.10 ADA and the question of statistical validity and representativeness of limited examination as the most relevant context. The two provisions are inextricably tied to each other - it is the practice of limited examination permitted under Article 6.10 ADA that necessitates Article 9.4 ADA, which refers to it explicitly.

If the exporters and/or producers selected (by USDOC, in the present case) are indeed a broad, statistically valid sample, as envisaged by Article 6.10 ADA, the fact that they all had zero or de minimis is significant. It would imply that the nonindividually calculated firms might very well have produced a similarly low dumping margin, if they had undergone individual review. Similarly, if all mandatory respondents' dumping margins were calculated on an AFA basis, this would imply that their real dumping margins are at least as high, and the investigative authority could perhaps impose a relatively high 'all others' rate, subject to other ADA rules.

This link between Articles 6.10 and 9.4 ADA gains support from a surprising source: the US claims in US-AD Shrimp. The US defended its 'all others' rate by arguing that its selection of the 'all others' rate from the original investigation and first administrative review constituted 'a reasonable method which is reflective of the range of commercial behaviour demonstrated by exporters of the subject merchandise during a very recent period' 65 and that 'there is no reason to find that

64 See US-AD Shrimp, para. 7.215.

65 Final Determination in the Second Administrative Review, p. 52275, Exhibit Viet Nam-15 to US-AD Shrimp; see also Issues and Decision Memo in the Second Administrative Review, p. 19, also Exhibit Viet Nam-15 to US-AD Shrimp. 
it is not reasonably reflective of potential dumping margins for the non-selected companies' (emphases added). ${ }^{66}$

We agree with this contention at a theoretical level: when all individually calculated dumping margins have been excluded by virtue of Article 9.4 ADA, the 'all others' rate should be 'reasonably reflective' of real commercial behaviour. However, we believe the best way to warrant this reflectiveness is by ensuring that the individually calculated dumping margins under Article 6.10 ADA are statistically valid and representative, as explained in depth in Section 3 above.

\section{Conclusions}

With the apparent demise of USDOC's zeroing methodology, it seems inevitable that the WTO system and its Members will turn their attention to other distortive practices pursued by investigating authorities in anti-dumping proceedings. The dispute in US-AD Shrimp demonstrates that the wholesale use of 'limited examination' under Article 6.10 ADA and the application of 'all others' rates to a large number of exporting firms constitutes such a distortive practice, leaving much to the potentially unprincipled discretion of the authority, and leaving many exporting firms with irrelevantly high dumping margins, and no recourse to administrative review in the Member imposing the anti-dumping duties.

In this paper, we have argued for a more rigorous application of the principles of statistical validity and representativeness in limited examination, and also shown how these principles can be the subject of judicial review by the WTO disputesettlement system. This also applies to the calculation of 'all others' rates, even in specialized circumstances. While the US-AD Shrimp dispute itself did not address these issues directly or forcefully enough, in our view, it can be expected that future disputes, in particular Viet Nam's follow-up complaint now being in process at the WTO, will provide better opportunity for their clarification. Sampling may well be the new zeroing.

\section{References}

Barfield, C. (2005), 'Anti-dumping Reform: Time to Go Back to Basics', The World Economy, 28(5): 719_ 737.

Bown, C. P. and A. O. Sykes (2008), 'The Zeroing Issue: A Critical Analysis of Softwood V', World Trade Review, 7(1): 121-142.

Bown, C. P. and T. J. Prusa (2011), 'US Anti-dumping: Much Ado About Zeroing', in Will Martin and Aaditya Matto (eds.), Unfinished Business? The WTO's Doha Agenda, Washington, DC: The World Bank, pp. 355-392.

Broude, T. (2007), 'Genetically Modified Rules: The Awkward Rule-Exception-Right Distinction in ECBiotech', World Trade Review, 6(2): 215-231.

66 Issues and Decision Memo in the Second Administrative Review, p. 19, Exhibit Viet Nam-15 to US-AD Shrimp. 
Business Times (Viet Nam) (2012), 'Vietnam’s Shrimp Export Reaches \$436Mln In Q1/2012', 17 May 2012, available at http://businesstimes.com.vn/vietnams-shrimp-export-reaches-436mln-in-q12012/ (last visited 28 November 2012).

Cho, S. (2012), 'No More Zeroing?: The United States Changes its Antidumping Policy to Comply with the WTO', ASIL Insights, 16(8): 1-7.

Debaere, P. (2010), 'Small Fish - Big Issues: The Effect of Trade Policy on the Global Shrimp Market', World Trade Review, 9(2): 353-374.

Department of Commerce (2009), 'Certain Frozen Warmwater Shrimp from the Socialist Republic of Vietnam: Issues and Decision Memorandum for the Final Results of the Third Antidumping Administrative Review', Public Document IA/NME/9: IG.

Do Thanh Cong (2010), 'Catfish, Shrimp, and the WTO: Vietnam Loses its Innocence', Vanderbilt Journal of Transnational Law, 43(5): 1235-1264.

Gantz, D. A. (2007), 'Doi Moi, the VBTA \& WTO Accession: The Role of Lawyers in Vietnam's No Longer Cautious Embrace of Globalization', The International Lawyer, 41(3): 873-890.

Gao, H. S. (2005), 'Aggressive Legalism: The East Asian Experience and Lessons for China', in Henry Gao and Donald Lewis (eds.), China's Participation in the WTO, London: Cameron May, pp. 315-351.

Helpman, E., M. J. Melitz, and S. R. Yeaple (2004), 'Export versus FDI with Heterogeneous Firms', The American Economic Review, 94(1): 300-316.

Keithly, W. R. Jr. and P. Poudel (2008), 'The Southeast USA Shrimp Industry: Issues Related to Trade and Antidumping Duties', Marine Resource Economics, 23(4): 459-483.

Lauterpacht, H. (1958), 'Some Observations on the Prohibition of "Non Liquet" and the Completeness of the Law', in F.M. van Asbeck et al. (eds.), Symbolae Verzijl: Présentées au Professeur J.H.W. Verzijl à l'Occasion de son LXX-ième Anniversaire, The Hague: Martinus Nijhoff, pp. 196-221.

Melitz, M. J. (2003), 'The Impact of Trade on Intra-Industry Reallocations and Aggregate Industry Productivity', Econometrica, 71(6): 1695-1725.

Moore, M. O. (2005), “"Facts Available” Dumping Allegations: When Will Foreign Firms Cooperate in Antidumping Petitions?', European Journal of Political Economy, 21(1): 185-204.

Moore, M. O. and A. K. Fox (2010), 'Why Don't Foreign Firms Cooperate in US Antidumping Investigations?: An Empirical Analysis', Review of World Economics, 145(4): 597-613.

Pauwelyn, J. (2003), Conflict of Norms in Public International Law: How WTO Law Relates to Other Rules of International Law, Cambridge: Cambridge University Press.

Pekkanen, S. M. (2001), 'Aggressive Legalism: The Rules of the WTO and Japan's Emerging Trade Strategy', The World Economy, 24(5): 707-737.

Prusa, T. J. and E. Vermulst (2009), 'A One-Two Punch on Zeroing: US-Zeroing (EC) and US-Zeroing (Japan)', World Trade Review, 8(1): 187-241.

- (2011), 'United States - Continued Existence and Application of Zeroing Methodology: The End of Zeroing?', World Trade Review, 10(1): 45-61.

Stone, J. (1959), 'Non Liquet and the Function of Law in the International Community', British Yearbook of International Law, 35: 124-161.

US Department of Commerce (2009), Import Administration Antidumping Manual, available at http://ia .ita.doc.gov/admanual/index.html (last visited 28 November 2012).

Van Damme, I. (2009), Treaty Interpretation by the WTO Appellate Body, Oxford: Oxford University Press.

Vo Tri Thanh and Nguyen Anh Duong (2009), 'Vietnam after Two Years of WTO Accession: What Lessons Can Be Learnt?', ASEAN Economic Bulletin, 26(1): 115-135.

Voon, T. (2011), 'Orange Juice, Shrimp, and the United States Response to Adverse WTO Rulings on Zeroing', ASIL Insights, 15(20): 1-7.

Weil, P. (1997), ““The Court Cannot Conclude Definitively ...”: Non Liquet Revisited', Columbia Journal of Transnational Law, 36(1-2): 109-119. 